\title{
Knowledge, attitude and practices concerning Hepatitis B infection, among healthcare workers in Bantama, Ghana: a cross sectional study
}

\author{
Mary Y. Afihene ${ }^{1 *}$, Babatunde M. Duduyemi², Hannah-Lisa A-Tetteh ${ }^{3}$, Mahafroz Khatib ${ }^{4}$
}

\begin{abstract}
${ }^{1}$ Department of Medicine, Kwame Nkrumah University of Science \& Technology, Kumasi, Ghana ${ }^{2}$ Department of Pathology, Kwame Nkrumah University of Science \& Technology, Kumasi, Ghana ${ }^{3}$ Department of Medicine, Komfo Anokye Teaching Hospital, Kumasi, Ghana

${ }^{4}$ Focus Scientific Research Center (FSRC) of Phamax AG, \#19, KMJ Ascend, 1st Cross, 17th C Main, 5th Block, Koramangala, Bangalore, India
\end{abstract}

Received: 05 May 2015

Revised: 03 June 2015

Accepted: 07 June 2015

\section{*Correspondence:}

Dr. Mary Y. Afihene,

E-mail: marykafihene@yahoo.com

Copyright: (C) the author(s), publisher and licensee Medip Academy. This is an open-access article distributed under the terms of the Creative Commons Attribution Non-Commercial License, which permits unrestricted non-commercial use, distribution, and reproduction in any medium, provided the original work is properly cited.

\section{ABSTRACT}

Background: Hepatitis B is a serious, global, public health problem that gives rise to hepatocellular carcinoma / liver cancer with a mortality rate of about 600000 people, worldwide. Despite increasing prevalence of HBV and health care workers (HCWs) being at high risk for HBV, there is paucity of information on knowledge, attitude and practice (KAP) concerning HBV among HCWs, especially among developing countries like Ghana. Improved HBV related knowledge is imperative for developing an informed positive environment which can import, support and maintain HVB control good practices.

Methods: This quantitative cross-sectional study aimed to evaluate KAP of HCWs was undertaken amongst 175 HCWs of Suntreso Government Hospital, Ghana. KAP regarding HBV were assessed using a standardized structured questionnaire. Descriptive statistics for patients' demographic characteristics and mean scores for knowledge, attitude and practice of HCWs were applied. To establish association between study variables, Kruskal Wallis test and to assess the association between the KAP scores, Spearman's rho correlation were used.

Results: Mean scores for KAP were 13.691 $\pm 2.81,6.685 \pm 2.28$ and $2.23 \pm 1.19$ respectively. Age, occupation and experience were significantly associated with mean knowledge scores $(\mathrm{p}<0.05)$. Spearman rank correlation revealed significant positive correlations between knowledge-attitude $(\mathrm{r}=0.539, \mathrm{p}<0.01)$, knowledge-practice $(\mathrm{r}=0.388, \mathrm{p}<$ $0.01)$ and attitude-practice $(\mathrm{r}=0.458, \mathrm{p}<0.01)$.

Conclusions: The study highlighted non-optimal KAP with regards to several aspects of HBV. Hence, there arises a need for policy guidelines along with extensive health education campaigns to manage all aspects of KAP of HCWs regarding $\mathrm{HBV}$.

Keywords: Hepatitis-B, KAP, Ghana, Healthcare workers

\section{INTRODUCTION}

Hepatitis B, the potentially life-threatening liver infection caused by the virus Hepatitis B (HBV), is a major global health problem which can cause chronic and often fatal liver diseases, such as liver cirrhosis and cancer. Globally, about two billion individuals have been infected with $\mathrm{HBV}$ at some point in time in their lifetimes and 360 to 400 million people (5\% of the world's population) are chronic carriers. HBV and its consequences are estimated to cause 600,000 deaths each year, a tenth of deaths worldwide. ${ }^{1}$

Of all the WHO regions, Africa is of particular interest. It is estimated that out of the 360 million chronic global carriers of $\mathrm{HBV}$, about 65 million of these chronic carriers live in Africa. ${ }^{2}$ In addition, of the estimated 1.3 million deaths recorded annually due to $\mathrm{HBV}$ related 
causes, about 250,000 are African. ${ }^{3}$ The exact HBV prevalence in Ghana is not known as different studies targeted different segments of the population and collectively, do not provide a clear picture of the situation on the ground. The 2009 Ghana Health Service report indicated that there had been an increase in the prevalence ratio of $\mathrm{HBV}$ infection from 8:1 in 2005 to $6: 1$ in $2009 .^{4}$

It is worth mentioning that in Ghana, hepatitis remains as one of the neglected infectious diseases and is yet to catch the attention of both policy makers and health experts. This is despite the fact that in developing countries like Ghana HBV infection is becoming in developing countries like Ghana, HBV infection becoming a serious public health problem and is a cause of morbidity and mortality. The factors that contribute to the rising worldwide prevalence of HBV are of particular relevance in Sub-Saharan Africa: lack of awareness, poverty, illiteracy and reticence to change. Though nosocomial transmission is not documented in most developing countries, this mode of transmission is apparently significant, giving the working conditions in most settings and the resources available for transmission prevention.

One of the important factors that several studies have persistently highlighted, is contacting HBV on the job, which is a concern among healthcare workers (HCWs) ${ }^{5-7}$ HCWs (general physicians, surgeons, dental surgeons, nurses, other medical staff) are considered at a highrisk of exposure to blood born viral diseases (i.e. HBV and Human Immunodeficiency Virus) via contact with blood and other body fluids in the course of their work. ${ }^{6,7}$ Studies have documented that the risk of nosocomial transmission of $\mathrm{HBV}$ following needle stick injury is between $6 \%-30 \%$ in susceptible HCWs who were not adequately vaccinated and did not receive post-exposure prophylaxis. ${ }^{6}$ Although $\mathrm{HBV}$ infection is completely preventable by following a simple and widely available vaccination schedule as well as other preventive measures, HCWs continue to get infected with this disease. The risk of occupational infections in such developing countries is intensified by a variety of factors, comprising but not restricted to, overcrowding in hospitals, lower HCWs' patient ratios, insufficient or absence of basic safety and protection equipment, partial awareness of exposure risk of blood and body fluid, and reutilizing/reprocessing contaminated needles and sharp instruments. ${ }^{6}$ This is alarming as they are expected to have been trained with the requisite knowledge as a safeguard against prevention of the virus. While public attitudes towards patients with HBV could represent a social issue, the knowledge and attitudes of HCWs towards HBV carries important implications for healthcare. Adequate knowledge and positive attitude are important for optimum care of patients living with HBV as it would generate a feeling of comfort in providing care.
HCWs are regarded as a reliable source of information to the public since they are expected to have adequate knowledge, if not better informed than the layman due to their field of practice, training and high illiteracy rate in the country. Testing their level of awareness is of the essence. Their responses can give a fair assessment of what the rest of the population knows about the disease. Assessing knowledge, attitude and practices (KAP) of HCWs can highlight the pre-requisite measures needed to be put in place to order to prevent or reduce risk of transmission among HCWs as well as give an approximate assessment of the knowledge of non medical individuals. Also, healthcare providers, if better trained could play a pivotal role in the implementation of control and prevention programs of HBV in Ghana. In view of the factors and forces facilitating the spread of the disease globally, being acquainted with the ground facts and figures while promoting positive attitudes and behaviors are of paramount importance in the fight against the spread of HBV.

In Ghana, there is no available literature to assess the knowledge, attitude and practices concerning HBV among HCWs. Therefore, the study has been conducted among HCWs to access the KAP concerning HBV in Ghana. Also, this study assesses the risk of transmission of $\mathrm{HBV}$, as inadequate knowledge, poor attitudes and practices of HCWs could serve as a potential threat to their patients, close contacts and society as a whole.

\section{Objective}

A quantitative cross-sectional study to access the KAP concerning HBV among HCWs in Suntreso Government Hospital, Ghana.

\section{METHODS}

The quantitative cross-sectional study was conducted in Suntreso Government Hospital (SGH) at Bantama, Kumasi Sub-Metro District in the Ashanti Region of Ghana from the December 09, 2013 to January 17, 2014. With a population just under two million, Kumasi is the second largest city in Ghana and the capital of the most populous region in the country, the Ashanti region. SGH is a district hospital and provides secondary care in North and South Suntreso, Patasi Estate, Kwadaso, Adoato, Asuoyeboa, Breman and Suame. HCWs comprising of doctors, nurses, midwives, dentists, pharmacists, technicians and sanitary workers working in the Suntreso Government Hospital during the study period were eligible for the study. The number of enrolled workers as provided by the Ghana Health Service, Human Resource Division, Staff Nominal Roll as at the second quarter, 2013 was 210, of which about 190 were HCWs with about twenty being non-HCWs. Out of which, 180 participants were selected using a non-probability sampling technique (purposive sampling). The instrument used for data collection was a self-developed, self- and researcher-administered standardized structured 
questionnaire. This contained both closed and openended questions to assess the perspectives of the respondents towards HBV. The purpose of the study was briefly explained to the respondents and strict confidentiality was assured. Individual informed consent was obtained together with the official permission granted by the hospital administration Descriptive statistics for demographic characteristics, percentages for categorical variables and mean \pm standard deviation for continuous variables were used to analyze the findings of the study. Inferential statistics (Kruskal Wallis tests, p < 0.05 ) were used to assess the significance among study variables. Spearman's rank correlation coefficient $(\mathrm{p}<$ 0.01) was used to evaluate the association between KAP components. This was conducted using Microsoft Excel and SPSS v. 16. All possible efforts were undertaken to address potential sources of bias during the study.

\section{RESULTS}

\section{Socio-demographic characteristics of study participants}

180 participants were confirmed eligible and included in the study. Out of 180 participants included in the study, 175 completed follow-up, and were analyzed, thereby giving a response percentage of about $97.22 \%$. Reasons for nonparticipation were documented. Out of a total of 175,12 were doctors/physician assistants, 88 nurses/midwives, 22 technicians, 20 sanitary workers and 33 fell under other HCWs. The majority was composed of nurses/ midwives, representing about $50 \%$ of the total population. Three $(1.71 \%)$ participants were below 18 years of age, fifty $(28.6 \%)$ were between the ages 18-25, eighty two (46.9\%) were between 26-35, twenty one $(12 \%)$ were between $36-45$ and nineteen $(10 \%)$ were $>45$. The majority of workers were in the 25-35 age group and represented $46.9 \%$ of the study population. As per hospital employment experience, seventy two workers (42\%) had worked for 3 years, twenty seven (16\%) had worked for 3-5 years, thirty one (18\%) had worked for 610 years, twenty eight (16\%) had worked for $10-15$ years and fourteen $(8 \%)$ had worked for $>15$ years (Table 1$)$.

\section{Knowledge about $\mathrm{HBV}$}

Each response on knowledge was labeled as 'yes' or 'no'. Knowledge was scored by giving 1 for a correct answer and 0 for a wrong answer. The scale measured knowledge from a maximum of 19 to a minimum of 0 . Scores $<10$ were taken as poor, $\geq 10$ as adequate knowledge of HBV. Mean knowledge was $13.691 \pm 2.81$ which is adequate knowledge.

Knowledge was assessed by asking questions about types, transmission modes and prevention of HBV. Out of the 175 participants, poor knowledge was apparent in responses to questions relating to types (question 1) and transmission of HBV through faeco-oral route (question 2f). Correct response rates to these questions range from 74-91.4\% for transmission of HBV (question 2), to 74.9-
$89.1 \%$ for preventive measures of $\mathrm{HBV}$ (question 4) (Table 2 and Figure 1).

Table 1: Demographic characteristics of the study respondents $(\mathbf{N}=\mathbf{1 7 5})$.

\begin{tabular}{|lll|}
\hline Variables & $\begin{array}{l}\text { Number } \\
(\mathbf{n})\end{array}$ & $\begin{array}{l}\text { Percentage } \\
(\%)\end{array}$ \\
\hline Age & & \\
\hline Up to 25 years & 53 & 30.28 \\
\hline $26-35$ & 82 & 45.71 \\
\hline Above 35 & 40 & 22.85 \\
\hline Occupation & \\
\hline Doctor & 12 & 6.85 \\
\hline Nurse/IM & 88 & 50.28 \\
\hline Sanitary/ Technician & 42 & 24 \\
\hline Others & 33 & 18.85 \\
\hline Years of experience & \\
\hline$<3$ & 72 & 41.14 \\
\hline $3-10$ & 58 & 33.14 \\
\hline $10-15$ & 28 & 16 \\
\hline$>16$ & 15 & 8.57 \\
\hline *Figures based on available data \\
\hline
\end{tabular}

Table 2: Responses to HBV knowledge items.

\begin{tabular}{|c|c|c|c|}
\hline $\begin{array}{l}\text { S. } \\
\text { No. }\end{array}$ & $\begin{array}{l}\text { Knowledge of } \\
\text { hepatitis }\end{array}$ & $\begin{array}{l}\text { Correct } \\
\text { responses } \mathbf{N} \\
(\%)\end{array}$ & $\begin{array}{l}\text { Incorrect } \\
\text { response } \mathbf{N} \\
(\%)\end{array}$ \\
\hline 1. & $\begin{array}{l}\text { Types } \\
\text { Hepatitis }\end{array}$ & $71(40.57)$ & $104(59.42)$ \\
\hline 2. & \multicolumn{3}{|c|}{ Transmission modes } \\
\hline a. & $\begin{array}{l}\text { Needle } \\
\text { Injury }\end{array}$ & $141(80.57)$ & $34(19.4)$ \\
\hline b. & $\begin{array}{l}\text { Vertical } \\
\text { Transmission }\end{array}$ & $128(73.14)$ & $47(26.85)$ \\
\hline c. & $\begin{array}{l}\text { Infected blood } \\
\text { transfusion }\end{array}$ & $160(91.4)$ & $15(8.5)$ \\
\hline d. & $\begin{array}{l}\text { Unsterilized } \\
\text { instruments }\end{array}$ & $140(80)$ & $35(20)$ \\
\hline e. & Sex & $144(82.28)$ & $31(17.7)$ \\
\hline f. & Faeco-oral route & $95(54.28)$ & $80(45.71)$ \\
\hline \multirow[t]{2}{*}{3.} & Prevention & & \\
\hline & $\begin{array}{l}\text { Whether HBV is } \\
\text { preventable }\end{array}$ & $157(89.71)$ & $18(10.28)$ \\
\hline 4. & \multicolumn{3}{|c|}{ Preventive measures } \\
\hline a. & Counseling & $137(78.28)$ & $38(21.7)$ \\
\hline b. & $\begin{array}{l}\text { Use of sterilized } \\
\text { instruments }\end{array}$ & $156(89.14)$ & $19(10.85)$ \\
\hline c. & $\begin{array}{l}\text { Practicing Safe } \\
\text { Sex }\end{array}$ & $150(85.71)$ & $25(14.28)$ \\
\hline d. & Hand washing & $131(74.85)$ & $44(25.14)$ \\
\hline \multicolumn{4}{|c|}{$\begin{array}{l}\text { Note: Knowledge was assessed by giving } 1 \text { to correct answer } \\
\text { and } 0 \text { to the wrong answer. The scale measured knowledge from } \\
\text { maximum } 19 \text { to minimum } 0 \text {. Scores }<10 \text { were taken as poor, } \geq \\
10 \text { as adequate knowledge of Hepatitis } B \text {. Mean knowledge was } \\
13.691 \pm 2.81 \text { which is adequate knowledge. }\end{array}$} \\
\hline
\end{tabular}


This table shows the knowledge about the symptoms of rabies; $24(21.6 \%)$ told about madness followed by hydrophobia $16(14.4 \%)$, bleeding $10(9 \%)$, fever 2 $(1.8 \%)$.

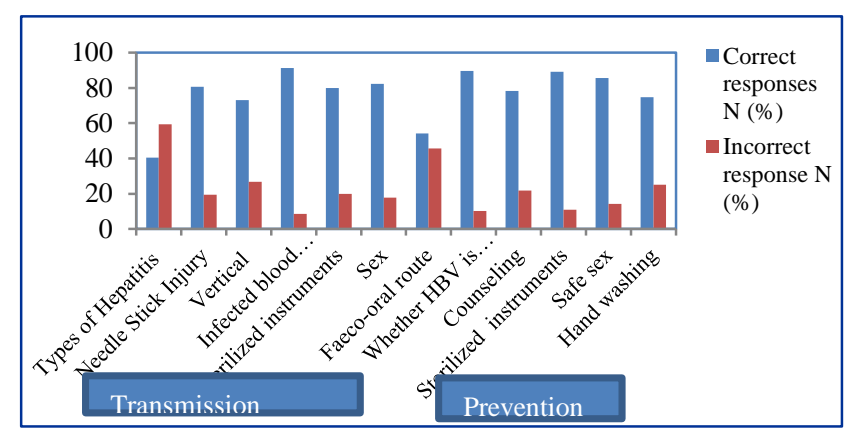

Figure 1: Responses to knowledge related to Hepatitis B.

\section{Attitude toward $\mathrm{HBV}$}

Attitude towards HBV was assessed by asking five questions, as shown in Table 3 and Figure 2 Each question was labeled with positive or negative attitude; the respondents were allowed to choose to only one response. Attitude was scored by giving 1-2 to positive and 0 to negative attitude. The scale classified attitude as positive with score $>6$ and negative $\leq 6$. Overall the respondents had a positive attitude towards HBV with mean score of $6.685 \pm 2.28$.

The majority of the participants $(89.3 \%)$ believed that HBV vaccination should be compulsory and $25.13 \%$ of the participants stated that they were scared of vaccination, while almost $2.28 \%$ of participants did not trust HBV vaccination. Out of the 175 study participants, $2.28-25.13 \%$ were within the negative attitude range whereas $69.14-91.9 \%$ showed a positive attitude towards HBV whereas $4.57-5.7 \%$ were unaware of the issues (Table 3 and Figure 2).

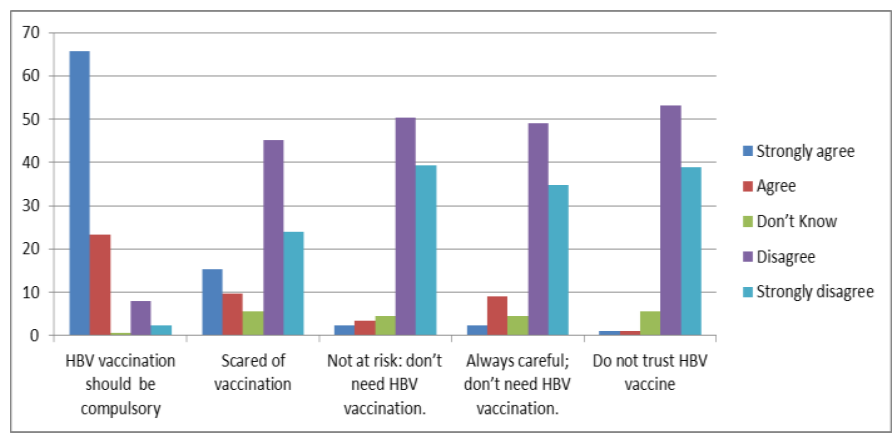

Figure 2: Responses to attitude related to Hepatitis $B$.

Table 3: Responses to attitude toward Hepatitis B.

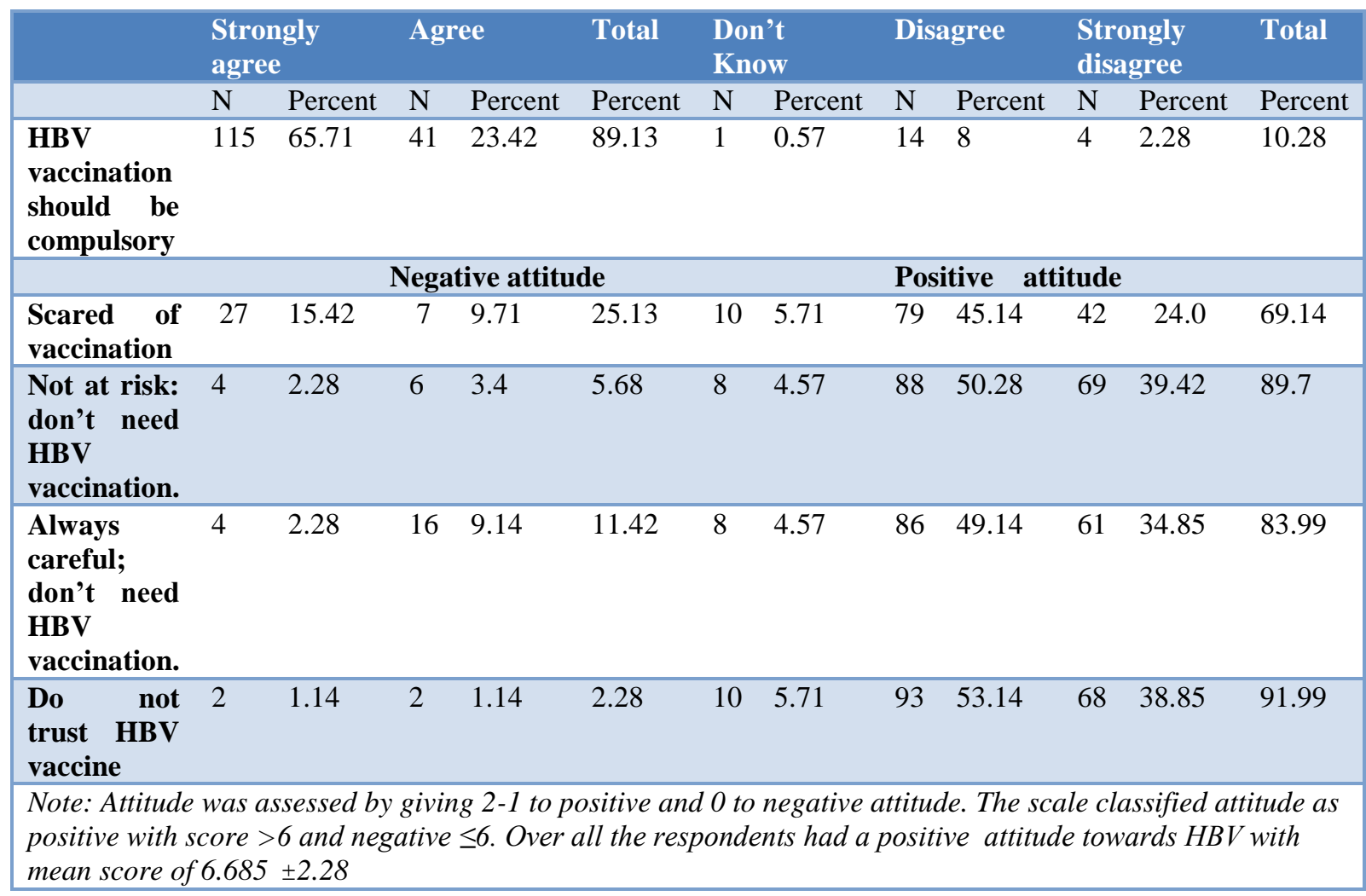




\section{Practices regarding $\mathrm{HBV}$}

Practices towards HBV were assessed as shown in Table 4 and Figure 3. Each question was labeled with good or poor practice. Practice was assessed by giving 1 to good practices and 0 to negative practices. The scale classified practice as good with score $>3$ and poor $\leq 3$. Over all the respondents reported to have poor practice towards $\mathrm{HBV}$ with mean score of $2.23 \pm 1.19$.

The majority of the HCWs (70.9\%) had never been exposed to needle stick injury. $43.1 \%$ participants had tested themselves after needle stick injury. $37.5 \%$ of the respondents had themselves tested for HBV within 21 days of needle stick injury. About $74.4 \%$ had taken HBV vaccine while about $41.8 \%$ had their immunity checked (Table 4 and Figure 3).

Table 4: Responses to practices related to Hepatitis B.

\begin{tabular}{|c|c|c|c|}
\hline Practices & Response & Number & Percent \\
\hline $\begin{array}{l}\text { Exposure to } \\
\text { needle stick injury }\end{array}$ & $\begin{array}{l}\text { Yes/Poor } \\
\text { No/Good }\end{array}$ & $\begin{array}{l}51 \\
124\end{array}$ & $\begin{array}{l}29.1 \\
70.9\end{array}$ \\
\hline $\begin{array}{l}\text { Tested after } \\
\text { needle stick injury }\end{array}$ & $\begin{array}{l}\text { Yes/Good } \\
\text { No /Poor }\end{array}$ & $\begin{array}{l}32 \\
124\end{array}$ & $\begin{array}{l}20.5 \\
79.4\end{array}$ \\
\hline $\begin{array}{l}\text { Days after which } \\
\text { tested }\end{array}$ & $\begin{array}{l}<21 \text { days/ } \\
\text { Good } \\
>21 \text { days/ } \\
\text { Poor }\end{array}$ & 12 & 37.5 \\
\hline $\begin{array}{l}\text { HBV vaccine } \\
\text { taken }\end{array}$ & $\begin{array}{l}\text { Yes/ } \\
\text { Good } \\
\text { No/ Poor }\end{array}$ & 53 & 30.2 \\
\hline Immunity checked & $\begin{array}{l}\text { Yes/ } \\
\text { Good } \\
\text { No/ Poor }\end{array}$ & 88 & 36.6 \\
\hline $\begin{array}{l}\text { If checked, } \\
\text { whether protected }\end{array}$ & $\begin{array}{l}\text { Yes/ } \\
\text { Good } \\
\text { No/ Poor }\end{array}$ & $\begin{array}{l}62 \\
18\end{array}$ & 22.5 \\
\hline \multicolumn{4}{|c|}{$\begin{array}{l}\text { Note: Practice was assessed by giving } 1 \text { to good } \\
\text { practices and } 0 \text { to negative practices. The scale classified } \\
\text { practice as good with score }>3 \text { and poor } \leq 3 \text {. Over all the } \\
\text { respondents reported to have poor practice towards } H B V \\
\text { with mean score of } 2.23 \pm 1.19 \text {. } \\
\text { *Figures based on available responses. Percentages based on available } \\
\text { responses }\end{array}$} \\
\hline
\end{tabular}

\section{Demographic characteristics and mean KAP scores association}

Association of demographic characteristics and mean KAP scores is presented in Table 5. Among the demographic variables, age, occupation and working experience were significantly associated with mean knowledge scores $(\mathrm{p}<0.05)$. A significant difference was found for age where respondents in age group up to 25 years had a significant association with those in age group 26-35 and above 35 years of age with respect to knowledge on HBV (p value - 0.0045). Similarly, a significant difference was also found in knowledge scores for occupation where doctors had a significant association with nurses and technicians ( $p$ value $<0.0001$ ) and in terms of working experience those with less than 3 years of experience had a significant association with those with 3-10, 10-15 and greater than 15 years of experience ( $p$ value - 0.0226). However, though differences were noted across the age, occupation and working experience with respect to attitude and practices scores no significant association was found between them.

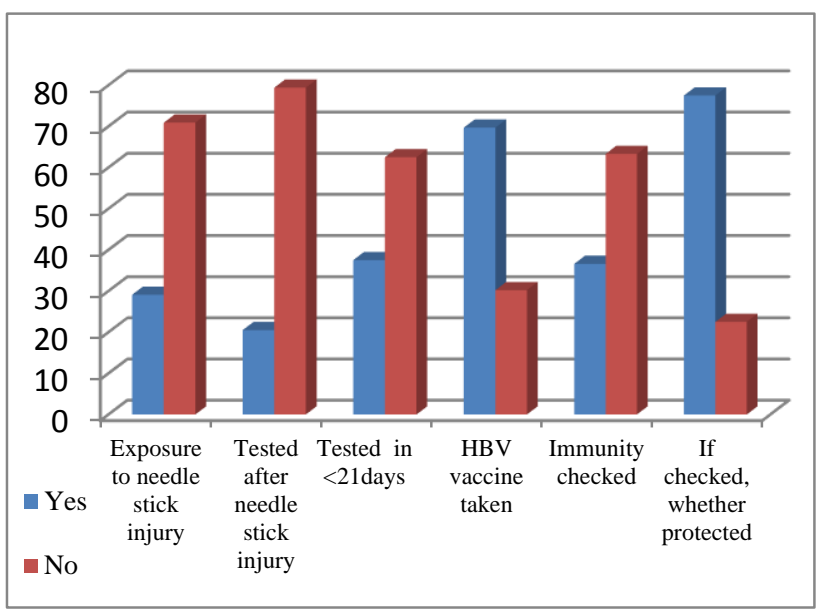

Figure 3: Responses to practices related to Hepatitis B.

\section{Correlation between KAP}

Spearman rank correlation revealed significant positive correlations between knowledge-attitude $(r=0.539, \mathrm{p}<$ $0.01)$, knowledge-practice $(\mathrm{r}=0.388, \mathrm{p}<0.01)$ and attitude-practice $(\mathrm{r}=0.458, \mathrm{p}<0.01)$. This result reaffirms the relationship between $\mathrm{KAP}$ of $\mathrm{HBV}$, as shown in Table 6. 
Table 5: Association of demographic characteristics and mean KAP scores.

\begin{tabular}{|c|c|c|c|c|c|c|c|}
\hline Variables & $\begin{array}{l}\text { Number } \\
\text { (n) }\end{array}$ & $\begin{array}{l}\text { Knowledge } \\
\text { score (Mean } \\
\pm \text { SD) }\end{array}$ & P value & $\begin{array}{l}\text { Attitude } \\
\text { score } \\
\text { (Mean } \\
\pm \text { SD) }\end{array}$ & $\begin{array}{l}\mathbf{P} \\
\text { value }\end{array}$ & $\begin{array}{l}\text { Practice } \\
\text { score } \\
\text { (Mean } \\
\pm \text { SD) }\end{array}$ & P value \\
\hline Age & & & \multirow[t]{4}{*}{$0.0045^{*}$} & & \multirow[t]{4}{*}{0.625} & & \multirow{4}{*}{0.0781} \\
\hline Up to 25 years & 53 & $15.24(2.4)$ & & $\begin{array}{l}8.30 \\
(1.9)\end{array}$ & & $\begin{array}{l}2.98 \\
(1.04)\end{array}$ & \\
\hline 26-35 years & 82 & $15.60(2.9)$ & & $\begin{array}{l}9.40 \\
(2.5)\end{array}$ & & $\begin{array}{l}3.47 \\
(1.1)\end{array}$ & \\
\hline Above 35 years & 40 & $16.45(2.3)$ & & $\begin{array}{l}8.89 \\
(2.1)\end{array}$ & & $\begin{array}{l}3.85 \\
(1.3)\end{array}$ & \\
\hline \multicolumn{8}{|l|}{ Occupation } \\
\hline Doctor & 12 & $16.40(0.9)$ & \multirow[t]{3}{*}{$<0.0001 *$} & $\begin{array}{l}9.81 \\
(2.3)\end{array}$ & \multirow[t]{3}{*}{0.301} & $\begin{array}{l}3.63 \\
(1.3)\end{array}$ & \multirow{3}{*}{0.6188} \\
\hline Nurse/IM & 88 & $16.22(2.7)$ & & $\begin{array}{l}9.05 \\
(2.2)\end{array}$ & & $\begin{array}{l}3.29 \\
(1.1)\end{array}$ & \\
\hline $\begin{array}{l}\text { Sanitary/ } \\
\text { Technician }\end{array}$ & 42 & $14.13(2.3)$ & & $\begin{array}{l}8.74 \\
(2.4)\end{array}$ & & $\begin{array}{l}3.38 \\
(1.05) \\
\end{array}$ & \\
\hline \multicolumn{8}{|l|}{ Experience } \\
\hline$<3$ years & 72 & $15.90(2.8)$ & \multirow[t]{4}{*}{$0.0226^{*}$} & $\begin{array}{l}8.57 \\
(1.9)\end{array}$ & \multirow[t]{4}{*}{0.7554} & $\begin{array}{l}3.26 \\
(1.1)\end{array}$ & \multirow{4}{*}{0.1479} \\
\hline $3-10$ years & 58 & $16.81(2.5)$ & & $\begin{array}{l}9.15 \\
(2.5)\end{array}$ & & $\begin{array}{l}3.35 \\
(1.1)\end{array}$ & \\
\hline $10-15$ years & 28 & $16.63(2.8)$ & & $\begin{array}{l}9.53 \\
(2.4)\end{array}$ & & $\begin{array}{l}3.52 \\
(1.3)\end{array}$ & \\
\hline$>16$ years & 15 & $17.43(3.1)$ & & $\begin{array}{l}8.92 \\
(2.5)\end{array}$ & & $\begin{array}{l}4.06 \\
(1.1)\end{array}$ & \\
\hline
\end{tabular}

Table 6: Correlation between KAP.

\begin{tabular}{|lll|}
\hline Variable & $\begin{array}{l}\text { Correlation } \\
\text { coefficient }\end{array}$ & P-value* \\
\hline Knowledge-Attitude & 0.539 & $<0.01$ \\
\hline Knowledge-Practice & 0.388 & $<0.01$ \\
\hline Attitude-Practice & 0.458 & $<0.01$ \\
\hline$*$ Correlation significant & at 0.01 levels & (2 tailed) \\
\hline
\end{tabular}

\section{DISCUSSION}

Results of the current study reveal that HCWs have poor KAP towards HBV with unsatisfactory knowledge about some important aspects of viral hepatitis. This is alarming because majority of the HCWs wrongly believed that HBV could be cured which, gives a hint on the depth of knowledge with regards to HBV. Overall knowledge was satisfactory amongst HCWs although the lack of knowledge on fatality of the disease, other types of viral hepatitis and non faeco-oral transmission route is disturbing since $\mathrm{HCW}$ s are in direct contact with the disease. Besides, though about a quarter had been exposed to needle stick injury, more than half of them showed a negative attitude towards testing after exposure and for those who did, testing was done after 3 weeks. Reasons attributed to this were that although there is easy access to facilities for testing, most HCWs only tested after needle stick injuries when the associated patient, from whom they got the prick, had a confirmed fatal or highly infectious blood-borne disease. Other reasons reported were time constraints and the fact that needle prick injuries have become a daily occurrence among colleagues, the majority of whom, remain apparently healthy. Although a majority had knowledge on the availability of HBV vaccine, it is still a source of concern because not only is the vaccine present in their working environment, but also that vaccination is usually done in the hospital and is the most popularized means of disease prevention. The majority of the workers had received vaccination indicating a positive attitude; the reasons given for not being vaccinated were mainly financial and time constraints. Thus, HCWs display negative attitudes and practices towards HBV transmission, especially, regarding testing after needle stick injury, checking of immunity after needle stick injury and its timing, as well as checking of immunity after vaccination, with the only positive attitude being that $74 \%$ had received vaccination. This goes to show that though knowledge on modes of transmission and prevention seems to be adequate, HCWs exhibit poor attitudes and practices on the job. 
Table 7: STROBE 2007 (v4) Statement_Checklist of items that should be included in reports of cross-sectional studies.

\begin{tabular}{|c|c|c|c|}
\hline Section/Topic & $\begin{array}{l}\text { Ite } \\
\mathbf{m} \\
\#\end{array}$ & Recommendation & $\begin{array}{l}\text { Rep } \\
\text { orte } \\
\text { d on } \\
\text { page } \\
\#\end{array}$ \\
\hline \multirow{2}{*}{$\begin{array}{ll}\text { Title } & \text { and } \\
\text { abstract }\end{array}$} & \multirow[t]{2}{*}{1} & (a) Indicate the study's design with a commonly used term in the title or the abstract & 1 \\
\hline & & $\begin{array}{l}\text { (b) Provide in the abstract an informative and balanced summary of what was done and what was } \\
\text { found }\end{array}$ & 1 \\
\hline \multicolumn{4}{|l|}{ Introduction } \\
\hline $\begin{array}{l}\text { Background/ratio } \\
\text { nale }\end{array}$ & 2 & Explain the scientific background and rationale for the investigation being reported & $2-3$ \\
\hline Objectives & 3 & State specific objectives, including any prespecified hypotheses & 3 \\
\hline \multicolumn{4}{|c|}{ ( } \\
\hline Study design & 4 & Present key elements of study design early in the paper & 3 \\
\hline Setting & 5 & $\begin{array}{l}\text { Describe the setting, locations, and relevant dates, including periods of recruitment, exposure, } \\
\text { follow-up, and data collection }\end{array}$ & 3 \\
\hline Participants & 6 & (a) Give the eligibility criteria, and the sources and methods of selection of participants & 3 \\
\hline Variables & 7 & $\begin{array}{l}\text { Clearly define all outcomes, exposures, predictors, potential confounders, and effect modifiers. } \\
\text { Give diagnostic criteria, if applicable }\end{array}$ & 3 \\
\hline $\begin{array}{l}\text { Data sources/ } \\
\text { measurement }\end{array}$ & $8^{*}$ & $\begin{array}{l}\text { For each variable of interest, give sources of data and details of methods of assessment } \\
\text { (measurement). Describe comparability of assessment methods if there is more than one group }\end{array}$ & 3 \\
\hline Bias & 9 & Describe any efforts to address potential sources of bias & 3 \\
\hline Study size & 10 & Explain how the study size was arrived at & 3 \\
\hline $\begin{array}{l}\text { Quantitative } \\
\text { variables }\end{array}$ & 11 & $\begin{array}{l}\text { Explain how quantitative variables were handled in the analyses. If applicable, describe which } \\
\text { groupings were chosen and why }\end{array}$ & 3 \\
\hline \multirow{5}{*}{$\begin{array}{l}\text { Statistical } \\
\text { methods }\end{array}$} & \multirow[t]{5}{*}{12} & (a) Describe all statistical methods, including those used to control for confounding & 3 \\
\hline & & (b) Describe any methods used to examine subgroups and interactions & 3 \\
\hline & & (c) Explain how missing data were addressed & \\
\hline & & (d) If applicable, describe analytical methods taking account of sampling strategy & \\
\hline & & (e) Describe any sensitivity analyses & 3 \\
\hline \multicolumn{4}{|l|}{ Results } \\
\hline \multirow[t]{3}{*}{ Participants } & $\begin{array}{l}13 \\
*\end{array}$ & $\begin{array}{l}\text { (a) Report numbers of individuals at each stage of study-eg numbers potentially eligible, } \\
\text { examined for eligibility, confirmed eligible, included in the study, completing follow-up, and } \\
\text { analysed }\end{array}$ & 3 \\
\hline & & (b) Give reasons for non-participation at each stage & 3 \\
\hline & & (c) Consider use of a flow diagram & \\
\hline \multirow[t]{2}{*}{ Descriptive data } & $\begin{array}{l}14 \\
*\end{array}$ & $\begin{array}{l}\text { (a) Give characteristics of study participants (eg demographic, clinical, social) and information on } \\
\text { exposures and potential confounders }\end{array}$ & $3-4$ \\
\hline & & (b) Indicate number of participants with missing data for each variable of interest & \\
\hline Outcome data & $\begin{array}{l}15 \\
*\end{array}$ & Report numbers of outcome events or summary measures & $3-5$ \\
\hline \multirow[t]{3}{*}{ Main results } & 16 & $\begin{array}{l}\text { (a) Give unadjusted estimates and, if applicable, confounder-adjusted estimates and their } \\
\text { precision (eg, 95\% confidence interval). Make clear which confounders were adjusted for and } \\
\text { why they were included }\end{array}$ & \\
\hline & & (b) Report category boundaries when continuous variables were categorized & $\begin{array}{l}\text { Tabl } \\
\text { e } 5\end{array}$ \\
\hline & & $\begin{array}{l}\text { (c) If relevant, consider translating estimates of relative risk into absolute risk for a meaningful } \\
\text { time period }\end{array}$ & \\
\hline Other analyses & 17 & Report other analyses done — eg analyses of subgroups and interactions, and sensitivity analyses & $4-5$ \\
\hline \multicolumn{4}{|l|}{ Discussion } \\
\hline Key results & 18 & Summarise key results with reference to study objectives & 5 \\
\hline Limitations & 19 & $\begin{array}{l}\text { Discuss limitations of the study, taking into account sources of potential bias or imprecision. } \\
\text { Discuss both direction and magnitude of any potential bias }\end{array}$ & 7 \\
\hline Interpretation & 20 & $\begin{array}{l}\text { Give a cautious overall interpretation of results considering objectives, limitations, multiplicity of } \\
\text { analyses, results from similar studies, and other relevant evidence }\end{array}$ & $5-6$ \\
\hline Generalisability & 21 & Discuss the generalisability (external validity) of the study results & 7 \\
\hline \multicolumn{4}{|l|}{$\begin{array}{l}\text { Other } \\
\text { information }\end{array}$} \\
\hline Funding & 22 & $\begin{array}{l}\text { Give the source of funding and the role of the funders for the present study and, if applicable, for } \\
\text { the original study on which the present article is based }\end{array}$ & 7 \\
\hline
\end{tabular}


The findings of the study is in agreement with that which was reported earlier, where poor knowledge levels of different populations from different regions were reported. ${ }^{8-13}$ However, these studies were related with the knowledge in healthy general population and there appears lack of data on the KAP of HCWs especially in developing countries like Ghana. Results of a past study suggests that not all practitioners are as knowledgeable as they could be. ${ }^{14}$ This is in line with many studies worldwide where, regardless of indications that failure for adherence to barrier precautions rises the exposure risk of mucocutaneous blood and body fluids, either poor level of compliance or sub optimal adherence has been reported widely. ${ }^{15-22}$ This includes studies that suggested that practitioners tend to increase the level of protection when they think a client is a high risk. ${ }^{23}$ Also, according to a study in Thailand, up to a quarter of doctors and nurses did not fully understand how to use protective barriers properly. ${ }^{24}$ However, constraints identified in our study coincide with findings of studies conducted among Thai and American nurses. ${ }^{16,17,25}$ In Sweden, despite the availability of free vaccine, seventy six percent HCWs were not vaccinated: they either forgot or never made appointments for vaccination. ${ }^{26}$ Similarly, in a study amongst UK nurses' reports that nurses did not finish their vaccination schedule despite having studied a course on vaccination, and midwives who were not immunized showed lack of awareness of the existence of the vaccine. ${ }^{27}$ Contrary to this, however, studies conducted in Iran and Egypt found high uptake of free vaccine among young surgeons. ${ }^{28,29}$

This is not surprising as attitudes and practices of individuals are reliant on multiple aspects that include culture, societal norms and individual beliefs. For instance, studies reveal that though HCWs are familiar with the necessary practice of use of gloves while drawing blood, few do not practice it due to the high patient: HCW ratio which leads to very busy schedules, unavailability of resources and financial constraints. This in turn, leads to inadequate amenities, equipment and working materials like gloves. Also, in certain health facilities, certain practices might not be considered as the norm and so may not be practiced regardless of the knowledge level. Attitudes are also associated with familiarity and what is considered as routine, e.g. in settings where the job description becomes a routine, HCWs may feel too familiar and too comfortable with their job and its practices with a subsequent tendency to lessen the necessary rigor required. These could be one of the factors that may account for poor attitude and practices regarding $\mathrm{HBV}$ transmission, in spite of satisfactory knowledge about modes of transmission and preventive measures. Workplace atmosphere, HCWs training, accessibility of supplies and a decent welldesigned management framework not only defines compliance but also modifies the attitude and practices therein. Further contributing factors are prevalent and must be elicited through advance studies for applicable interventions.
In the present study, the age, occupation and years of experience were the significant demographic factors associated with the mean KAP scores. While in other studies across the globe, education level was found to be significantly associated with KAP scores $^{13,30}$ literature reporting relationship between occupation or age and years of experience of HCWs with KAP is lacking.

The positive correlations between knowledge-attitude, knowledge-practice and attitude-practice in this study confirm the relationship between knowledge attitude and practice with infection control measures. It is concluded that satisfactory knowledge can bring about a positive attitude, leading to good practices. The findings are consistent with the results of some previous studies; however, such results included healthy population and no data are reported from the perspective of HCWs. ${ }^{8,31}$ The theory of Reasoned Action explains the reported positive correlations. An individual's intention to perform a particular behavior is a function of their attitude on the road to that behavior. Besides, attitude toward conduct is determined by the individual's belief that a certain outcome will arise if one adheres to that conduct. ${ }^{32}$ In this context, in the present study, HBV practices as a performed conduct were influenced by the attitude of the HCWs towards HBV. Furthermore, the attitude was moulded according to the knowledge that the HCW possesses about HBV. Therefore, it is concluded that accurate knowledge leads positive attitude which in turn results in a positive change in the practices of $\mathrm{HCW}$.

\section{CONCLUSION}

This study highlights the disparities in knowledge amongst HCWs and has brought to the fore a wide gap between knowledge and practices that would protect health personnel against $\mathrm{HBV}$. For HCWs, the KAP is especially disturbing because they serve as a source of information to the patients they work with and may be passing down wrong information to them. This also goes a long way into determining the attitudes and practices towards the disease as more caution is to be employed with fatal diseases, in comparison to disease with available and effective treatment options. Also, this HBV related dearth of knowledge can be contributory towards increasing frequency of $\mathrm{HBV}$. Hence, educational campaigns among HCWs should be intensified with focus being on attitude change and behavior modification. Governments should make screening programs for the infection free of charge, reduce the cost of the vaccine and make vaccination compulsory, especially for HCWs. The government can do this by including $\mathrm{HBV}$ immunization in the preventive services in the National Health Insurance Scheme (NHIS). Also HCWs should be encouraged to investigate their status of immunity against HBV, especially those who are at an increased high risk. The Ministry of Health, the Ghana Health Service and its institutions need to develop specific policies on the practice of Universal Basic Precautions (UBP); train healthcare providers in the 
implementation of UBP; ensure consistent supply of all protective materials at all times within institutions. Empowering the HCWs can aid in disease management along with governing the further spread of infection to the healthy residents.

\section{Limitations}

Inadequate responses, small sample size, inadequate financial resources and time constraints limited the scope of the study but the study serves a good starting point for more extensive future research in the area with the aim of giving the patients optimum care whilst being careful not to compromise HCW's own health in the process. The survey sample was not a probability sample and therefore not representative of all HCWs in Ghana; therefore, the study findings should be generalized with caution.

\section{Funding: No funding sources}

Conflict of interest: None declared

Ethical approval: The study was approved by the ethics committee

\section{REFERENCES}

1. World Health Organization. Hepatitis Fact sheet N204 Revised August 2008. Key facts. Where is Hepatitis B most common? Available at: www.who.int/mediacentre/factsheets/fs204/-29k. Accessed 2 Feb 2015.

2. World Health Organization. Global Burden of Diseases Update. Geneva. World Health Organization, 2004 (WHO/W74/2004).Available at: http://www.who.int/healthinfo/global_burden_disea se/GBD_report_2004update_full.pdf. Accessed 2 Feb 2015.

3. Kew M. Chronic hepatitis B virus infection and hepato-cellular carcinoma in Africa. S Afr Jr Sci. 1992;88:524-8.

4. GHS Annual Report 2009- Ghana Health Services. Available www.ghanahealthservice.org/.../Final_Draft 2009 GHS_Annual_Report\%20final\%final. Accessed 2 Mar 2015.

5. Shakhgildian IV, Paktoris EA, Khukhlovich PA, Zhukova LD. Hepatitis B as nosocomial infection (aspects of epidemiology and prevention. Vestn Ross Akad Med Nauk. 1996;(3):50-5.

6. Tarantola A, Abiteboul D, Rachline A. Infection risks following accidental exposure to blood or body fluids in healthcare workers: a review of pathogens transmitted in published cases. Am J Infect Control. 2006;34:367-74.

7. Dement JM, Epling C, Ostbye T, Pompeii LA, Hunt DL. Blood and body fluid exposure risks among health care workers: results from the Duke Health and Safety Surveillance System. Am J Ind Med. 2004;46:637-48

8. Haq NU, Hassali MA, Shafie AA, Saleem F, Farooqui M, et al. A cross sectional assessment of knowledge, attitude and practice towards Hepatitis B among healthy population of Quetta, Pakistan. BMC Public Health. 2012;12(1):692.

9. Wu CA, Lin SY, So SK, Chang ET. Hepatitis B and liver cancer knowledge and preventive practices among Asian Americans in the San Francisco Bay Area. California. Asian Pac J Cancer Prev. 2007;8(1):127-34.

10. Haider G, Haider A. Awareness of women regarding hepatitis B. J Ayub Med Coll Abbottabad. 2008;20(4).

11. van der Veen YJJ, Voeten HACM, de Zwart O, Richardus JH. Awareness, knowledge and selfreported test rates regarding Hepatitis B in TurkishDutch: a survey. BMC Public Health 2010;10(1):512.

12. Nguyen TT, Taylor V, Bastani R, Maxwell AE, Mcphee SJ. Hepatitis B awareness, knowledge, and screening among Asian Americans. J Cancer Educ. 2007;22(4):266-72.

13. Taylor VM, Tu SP, Woodall E, Acorda E, Chen H, et al. Hepatitis B knowledge and practices among Chinese immigrants to the United States. Asian Pac J Cancer Prev. 2006;7(2):313-7.

14. Knight V. Perceptions and Practice of universal blood and body fluid precautions by registered nurses at a major Sydney Teaching Hospital. J Advan Nurs. 1998;27(4):746-51.

15. Kermode M, Jolley D, Langkham B, Thomas M, Crofts N. Occupational exposure to blood and risk of blood borne virus infection among health care workers in rural North Indian settings. Am J Infect Control. 2005;33:34-41.

16. Gershon R, Vlahov D, Felknor SA, Vesley D, Johnson PC, et al. Compliance with Universal precautions among health workers at three regional hospitals. Am J Infect. Control. 1995;23:225-36.

17. Kelen G, DiGiovanni TA, Celentano DA. Adherence to universal (barrier) precautions during interventions on critically and injured emergency department patients. J Acquir Immune Defic Syndr. 1990;3:987-94.

18. Singru SA, Banerjee A. Occupational exposure to blood and body fluids among health care workers in a teaching hospital in Mumbai, India. Indian $\mathbf{J}$ Community Med. 2008;33:26-30.

19. Jovic-Vranes A, Bjegovic-Mikanovic V, Marinkovic. Safety practices and professional exposure to blood and blood containing materials. J Occup Health. 2006;48:377-82.

20. United States Agency for International Development. Evaluation of injection safety and healthcare waste management in Nigeria: 2009 comparison report. Available at: http://pdf.usaid.gov/pdf_docs/PNADR651.pdf. Accessed 10 Mar 2015.

21. Sadoh WE, Fawole AO, Sadoh AE, Oladimeji AO, Sotiloye OS. Practice of universal precautions among health care workers. J Natl Med Assoc. 2006;98(5):722-6. 
22. Gershon R, Karkashian CD, Vlahov D, Kummer L, Kasting C. Compliance with Universal Precautions in Correctional Health Care Facilities. JOEM. 1999;41(3):181-9.

23. Hartley Troya S. A survey of nurses' knowledge, opinions and reported uses of body substance isolation systems. Am J Of Infect Contr.1991;19(6):268-76.

24. Danchaivijitr S, Tantiwatanapaiboon Y, Chokloikaew S, Tangtrakool T, Suttisanon L, et al. Universal precautions: knowledge, compliance and attitudes of doctors and nurses in Thailand. $\mathrm{J}$ Med Assoc Thai. 1995;78(2):S112-7.

25. Ramsey PW, McConnell P, Palmer BH, Glen LL. Nurses' compliance with universal precautions before and after implementation of OSHA regulations. Clin Nurs Spec. 1996;10:234-9.

26. Delsenhammer S, Radon K, Nowark D, Reichert J. Needle sticks injuries during medical training. J hosp infect. 2006;63:263-7.

27. Lee R. Occupational transmission of blood borne diseases to health care workers in developing countries: meeting the challenges. J hosp infect. 2008;1-10.
28. Alam Knowledge, attitudes and practices among health care workers on needle stick injuries. Anals of Saudi medicine. 2002;22(5-6):396-9.

29. Moghimi M, Marashi SA, Kabir A, Taghipour HR, Faghihi-Kashani AH, et al. Knowledge attitudes of Iranian surgeons about blood borne disease. J Surg Res. 2009; 151(1):80-4.

30. Cheung J, Lee TK, Teh CZ, Wang C, Kwan W, Yoshida EM. Cross-sectional study of hepatitis B awareness among Chinese and Southeast Asian Canadians in the Vancouver-Richmond community. Can J Gastroenterol. 2005;19(4):245-9.

31. Singh A, Purohit B. Knowledge, Attitude and Practice towards Infection Control Measures and it's Correlation among Dental Students in Bhopal city. Central India. Int J Infect Control. 2010;7(1):1-9.

32. Fisher WA, Fisher JD, Rye BJ. Understanding and promoting AIDS-preventive behavior: Insights from the theory of reasoned action. Health Psychol. 1995;14(3):255-64.

Cite this article as: Afihene MY, Duduyemi BM, ATetteh HL, Khatib M. Knowledge, attitude and practices concerning Hepatitis B infection, among healthcare workers in Bantama, Ghana: a cross sectional study. Int J Community Med Public Health 2015;2(3):244-53. 